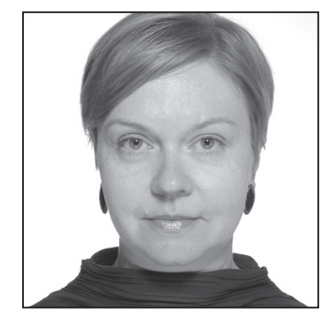

Kärt Nemvalts

Mag. iur.

Adviser, Private Law Division

Ministry of Justice

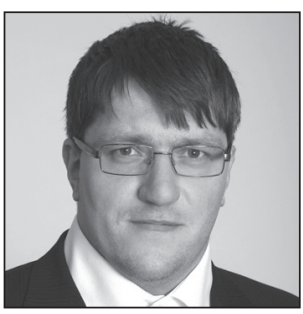

Aleksei Kelli

Associate Professor

of Intellectual Property Law

University of Tartu

\title{
The Estonian Perspective on the Transposition of the Directive on Collective Management of Copyright and Related Rights
}

\section{Introduction}

The collective management of copyright and related rights in independent Estonia ${ }^{{ }^{*} 1}$ has a relatively short history in comparison to many other European countries. The Estonian Copyright Act ${ }^{* 2}$ contains a separate chapter on collective rights management (CRM). ${ }^{*}$ Absence of state supervision of collective management organisations (CMOs) distinguishes Estonia from many other EU countries. ${ }^{*}{ }^{*}$ There has not been any substantial need to review this approach in the Estonian Copyright Act. The regulatory framework for CMOs' activities has functioned well; therefore, it has not been significantly amended. ${ }^{*}$

1 Since it is not relevant in the context of this article, the authors do not address the collective rights management during the Soviet period. However, it should be mentioned that on 27 February 1973, the Soviet Union became a party to the Geneva version, of 1952, of the Universal Copyright Convention (UCC). The UCC entered effect in the USSR on 27 May 1973. In the same year (on 20 September), the All-Union Agency on Copyrights (Vsesoiuznoe agentstvo po avtorskim pravam, or VAAP) was established. This body managed copyrights on foreign works in the USSR and also the copyrights on Soviet works abroad. See M. Boguslavski. Rahvusvahelise autoriõiguse kaitse NSV Liidus (Protection of International Copyrights in the Soviet Union). Tallinn: Kirjastus "Eesti Raamat" 1976, pp. 16-17, 53-54.

2 Autoriõiguse seadus. - RT I, 29.10.2014, 4 (in Estonian). English text available at https://www.riigiteataja.ee/en/ eli/531102014005/consolide (most recently accessed on 20.2.2015).

3 Chapter IX of the Copyright Act.

4 This does not mean that CMOs are totally free in their activities from government interference and control. For instance, according to the Copyright Act, 'the Government of the Republic shall establish by a regulation the procedure for payment of remuneration to compensate for private use of audio-visual works and sound recordings of works and the list of storage media and recording devices' (§27 (14) 1)).

5 Actually, the whole Copyright Act currently in force has functioned relatively well, and we can acknowledge the high-quality work done by its drafters in the early 1990s. For further discussion of the history of the Estonian copyright system, see H. Pisuke. Developments in Estonian Intellectual Property Law: Some Issues concerning Copyright and Related Rights. Juridica International 1999/IV, pp. 166-171. 
Also, the Estonian collective management organisations can be characterised as stable and efficient organisations. The Estonian Authors' Society (Eesti Autorite Ühing, EAÜ) ${ }^{*} 6$ was established on 8 October 1991 as the successor in title to a similar society established in Estonia in 1932. Some years later, in 1998, the Estonian Association of the Phonogram Producers (Eesti Fonogrammitootjate Ühing, EFÜ) ${ }^{*} 7$ was established, with the Estonian Association of Audiovisual Authors (Eesti Audiovisuaalautorite Liit, EAAL) ${ }^{* 8}$ following in 1999 and the Estonian Performers Association (Eesti Esitajate Liit, EEL) ${ }^{*}$ in 2000. No major changes in the number of organisations have occurred during the time those organisations have represented the respective groups of rights-holders.

Only one minor incident took place, in 2001, when the Estonian Association of Music and Phonogram Producers (Eesti Muusika- ja Fonogrammitootjate Liit, EMFL) was established as an alternative organisation to represent producers of phonograms. This caused some confusion among stakeholders. However, the organisation was active for only a very short time and has been liquidated.

As a result, it can be said that both the regulation pertaining to collective rights management and CMOs themselves function quite well in Estonia and that there is no need for reviewing the underlying, basic principles of the CRM system. This does not mean that all possible changes are ruled out. For instance, a draft regulation is being prepared that introduces extended collective licensing. ${ }^{*}{ }^{10}$ This draft regulation is based on research conducted by Elise Vasamäe. Since her research results are presented in sufficient detail in her $\mathrm{PhD}$ thesis ${ }^{* 11}$, examining this proposed change is not our primary focus.

The main focus of this article is on the topical issues linked to transposition of the Collective Rights Management Directive ${ }^{* 12}$ (or CRM Directive) into Estonian legislation. It is disputable whether the CRM Directive improves the Estonian copyright system. However, since Estonia is an EU member state, it has to transpose the directive. This complicated and demanding practical work is currently underway in the Estonian Ministry of Justice. The article has been written to share the Estonian experience with foreign experts who are facing similar challenges.

The transposition of the CRM Directive results in significant changes entailing at least some administrative burden on the state and stakeholders. In the following sections of the paper, the authors address the most challenging practical and theoretical issues, including cross-border rights management, competition and cultural issues, and the supervision of CMOs.

In dealing with the above-mentioned issues, the authors rely on traditional legal methods such as analytical and comparative approaches. Additional insights and contextual information related to CMOs' activities were obtained through communication with Kalev Rattus, from the Estonian Authors' Society. ${ }^{* 13}$

\section{Cross-border rights management}

One of the arguments for adoption of the CRM Directive was the liberalisation and clarification of issues of cross-border rights management. There is some confusion as to whether rights management constitutes a service that is subject to the Directive of the European Parliament and of the Council on Services in the Internal Market ${ }^{*}{ }^{4}$ (the Services Directive).

6 Additional information available at http://www.eau.org/ (most recently accessed on 20.2.2015).

Additional information available at http://www.efy.ee/ (most recently accessed on 20.2.2015).

Additional information available at http://www.kinoliit.ee/eaal (most recently accessed on 20.2.2015).

9 Additional information available at http://www.eel.ee/ (most recently accessed on 20.2.2015).

10 See Seletuskiri autoriõiguse ja autoriõigusega kaasnevate õiguste seaduse eelnõu juurde. Versioon: 21.7.2014 (Explanatory Memorandum to the Estonian draft Copyright and Related Rights Act, Version: 21.7.2014) (in Estonian). Available at https:// ajaveeb.just.ee/intellektuaalneomand/wp-content/uploads/2014/o8/Autori\%C3\%B5iguse-seletuskiri-21-7-2014.pdf (most recently accessed on 8.1.2015).

$11 \quad$ E. Vasamäe. Autoriõiguste ja autoriõigusega kaasnevate õigustejätkusuutlik kollektiivne teostamine ['Sustainable Collective Management of Copyright and Related Rights'], prepared under the supervision of Professor Heiki Pisuke. Tartu Ülikooli Kirjastus 2014, p. 113. Available at http://dspace.utlib.ee/dspace/handle/10062/42432 (most recently accessed on 17.3.2015).

12 Directive 2014/26/EU of the European Parliament and of the Council of 26 February 2014 on Collective Management of Copyright and Related Rights and Multi-territorial Licensing of Rights in Musical Works for Online Use in the Internal Market. - OJ L 84, 20.3.2014, pp. 72-98.

13 E-mail communications with Managing Director Kalev Rattus (9.4.2015; 13.4.2015; 14.4.2015).

14 Directive 2006/123/EC of the European Parliament and of the Council of 12 December 2006 on Services in the Internal Market (OJ L, 27.12.2006, 376/36). 
Shortly after the adoption of the CRM Directive, the European Court of Justice (ECJ) rejected the European Commission's arguments for the applicability of the Services Directive to CMOs' activities (with the so-called OSA judgement). ${ }^{*} 15$ The ECJ acknowledged that CMOs provide a 'service' within the meaning of the Services Directive but then excluded the applicability of the Services Directive to intellectual property by making a reference to Article 17 (11) of the Services Directive. ${ }^{* 16}$ The ECJ further explained that legislation that grants a CMO a monopoly over the management of copyright in the territory of the Member State concerned should be considered suitable for protecting intellectual property rights, since it is liable to allow the effective management of those rights and effective supervision of their respect in the relevant territory. According to the ECJ, allowing users of works to obtain authorisation for the use of those works and pay the fees due through any collecting society established in the EU could lead to significant monitoring problems related to the use of those works and the payment of the fees due. ${ }^{*}{ }^{17}$ This judgement supports the approach of countries that have a high level of control over CMOs in their territory. ${ }^{*} 8$ That control can be exercised through a set of requirements that collective rights management organisations are required to meet. Collective rights management organisations' activities are closely linked to their organisational form. Estonian copyright law does not provide legal definition of a CMO. ${ }^{* 19}$ However, according to the Estonian Copyright Act, "[a] collective management organisation shall be a non-profit association which is founded, operates or is dissolved pursuant to the Non-profit Associations Act'. ${ }^{20}$

On the European Union level, the definition of a collective management organisation was initially provided in the cable and satellite directive. ${ }^{{ }^{21}}$ At the same time, no compulsory organisational form was specified. ${ }^{{ }^{22}}$ Therefore, any organisation, in any legal form, could operate as a collective management organisation. The CRM Directive sets forth more details regarding the definition and thereby narrows the category of organisations that can be considered to be collective management organisations.

Nevertheless, in comparison with what is specified in the Estonian Copyright Act, this definition is still broader. According to the legal literature, the local requirements being stricter obliges the EU Member State in question to stipulate such a broad definition in its relevant legislation as well. It is not in conformity with the Services Directive to require a certain legal form for collective management organisations in a Member State. ${ }^{* 23}$ The current regulation, wherein strict requirement of a specific legal form exists, could lead to a situation in which collective management organisations established in other Member States that take different legal forms could not provide services. This might have been the case before the CRM Directive was adopted (local requirements in Member States contradicting the Services Directive). ${ }^{*} 4$

15 Case C-351/12, Ochranný svaz autorský pro práva k dílům hudebním o.s. (OSA) vs Léčebné lázně Mariánské Lázně a.s., paragraph 65. Available at http://curia.europa.eu/juris/documents.jsf?num=C-351/12 (most recently accessed on 5.3.2015).

16 Article 16 ('Freedom to provide services') shall not apply to copyright, neighbouring rights, and industrial property rights, according to Article 17 of the Services Directive.

17 Case C-351/12, paragraphs 63, 64, 72, and 77.

18 For instance, the Latvian Copyright Law foresees that 'only one organisation for collective management of economic rights without an authorisation from another organisation for collective management shall perform collective management of economic rights in relation to public lending, as well as reproduction and reprographic reproduction for personal use' ( $\$ 63$ (8)). English text available at http://www.gencs.eu/uploads/european_patent_trademark_registration/latvia/Copyright\%20 Law\%20Latvia.pdf (most recently accessed on 24.3.2015). The Polish Copyright Law gives specific instructions for a case wherein, in a given field of exploitation, there is more than one collective management organisation (\$107). English text is available at http://www.wipo.int/wipolex/en/text.jsp?file_id=129378 (most recently accessed on 24.3.2015). The Czech Copyright Law's Section 97 (2) requires that the 'collective rights manager [...] only be a legal person with its seat in the Czech Republic and associating, directly or through a third party, rightholders whom he represents in collective rights management'. Also, pursuant to Section 98, there should be authorisation obtained from the Ministry of Culture to execute collective rights management. English text of this law is available at http://www.wipo.int/wipolex/en/text.jsp?file_id=137175 (most recently accessed on 24.3.2015).

19 See also the Czech Copyright Law's Section 97 (3), which stipulates: 'Collective rights management is not a business enterprise': English text available at http://www.wipo.int/wipolex/en/text.jsp?file_id=137175 (most recently accessed on 24.3.2015). In Hungary, the collective management of rights is subject to registration, pursuant to Section 86 (1) of the Hungarian Copyright Act. English text is available at http://www.hipo.gov.hu/English/jogforras/hungarian_copyright_act. pdf (most recently accessed on 24.3.2015).

20 Copyright Act, $\$ 76(2)$.

21 Council Directive 93/83/EEC of 27 September 1993 on the Coordination of Certain rules Concerning Copyright and Rights Related to Copyright Applicable to Satellite Broadcasting and Cable Retransmission (OJ L, 6.10.1993, 248).

22 Article 1 (4) of the cable and satellite directive (Directive 93/83/EEC).

23 E. Vasamäe (see Note 12), pp. 113, 146.

24 Under Article 16 (1) of the Services Directive, 'Member States shall respect the right of providers to provide services in a Member State other than that in which they are established'. Article 17 excludes certain fields from the scope of application of Article 16, 
The authors of this article are of the opinion that conflict between a local legal-form requirement and Article 16 of the Services Directive is not evident in light of the recent CRM Directive. Pursuant to the CRM Directive, a collective management organisation 'means any organisation which is authorised by law or by way of assignment, licence or any other contractual arrangement to manage copyright or rights related to copyright on behalf of more than one right holder, for the collective benefit of those right holders, as its sole or main purpose, and which fulfils one or both of the following criteria: (i) it is owned or controlled by its members; (ii) it is organised on a not-for-profit basis; [...]'. Recital 14 facilitates interpretation by clarifying that the CRM Directive does not require collective management organisations to adopt a specific legal form. In practice, these organisations operate in various legal forms in different Member States, such as associations, co-operatives, or limited-liability companies and in some exceptional cases as foundations ${ }^{* 25}$. The practice referred to does not violate the provisions of the CRM Directive. Nothing prevents a Member State from stipulating its own formalities for establishment of a collective management organisation. According to the CRM Directive, rights-holders have the right to authorise a collective management organisation of their choice to manage the rights, categories of rights or types of works, and other subject matter of their choice, for the territories of their choice, irrespective of the Member State of nationality, residence, or establishment of either the collective management organisation or the rights-holder. ${ }^{*}{ }^{*}$ With regard to the freedoms established in the Treaty on the Functioning of the European Union (TFEU) ${ }^{* 27}$, collective management of copyright and related rights should entail a rights-holder being able freely to choose a collective management organisation for the management of his rights. ${ }^{*}{ }^{28}$ As a result, Estonian authors are entitled to authorise, for instance, a French CMO to manage their rights in the whole EU (including Estonia). The legal form of the French CMO is irrelevant.

This approach is supported by the initial proposal of the CRM Directive. ${ }^{{ }^{2} 29}$ Recital 3 of the proposal clarifies the issue of applicability of the Services Directive by asserting that collective management organisations as service providers should comply with the national requirements pursuant to the directive. The recital further explains that 'collecting societies should be free to provide their services across borders, to represent rightholders resident or established in other Member States or grant licences to users resident or established in other Member States'. ${ }^{*}{ }^{30}$ The final version of the CRM Directive, however, does not make similar reference to the Services Directive. Still it can be asserted that the Services Directive is applicable since Recital 8 of the CRM Directive refers to Article 62 of the TFEU, which deals with a sector offering services across the European Union as one of its legal bases.

A practical question to be answered in the drafting of the relevant provisions for the Estonian Copyright Act is whether the CRM Directive obliges Estonia to follow the wording of said directive in providing a requirement of a specific legal form for collective management organisations or whether it instead may be possible or even preferable to retain the existing definition for CMOs established in Estonia. The authors of this article support the adoption of a broad definition as provided in the CRM Directive. At the moment, the authors prefer to rely on the wording put forward by Vasamäe in her PhD thesis: 'A collective management organisation established in any legal form in another member state of the EU or a state that is a contracting party to the EEA Agreement and that conforms to the criteria for a collective management organisation

including copyright and neighbouring rights (Article 17 (11)). It has been disputed whether collective management services too are included in the scope of derogation in Article 17 (11) or not. If collective management is not exempted from the scope of Article 16 of the Services Directive, no restrictions could be introduced to entering the market of another Member State for provision of collective management services. See J. Drexl et al. Comments of the Max Planck Institute for Intellectual Property and Competition Law on the proposal for a directive of the European Parliament and of the Council on collective management of copyright and related rights and multi-territorial licensing of rights in musical works for online uses in the internal market COM (2012)372 (Max Planck Institute for Intellectual Property and Competition Law Research Paper No. 13-04), pp. 17-18. Available at http:// papers.ssrn.com/sol3/papers.cfm?abstract_id=2208971 (most recently accessed on 23.3.2015).

25 Pursuant to $§ 1$ of the Estonian Foundations Act. Sihtasutuste seadus (Foundations Act). - RT I 1995, 92, 1604; RT I, 29.6.2014, 109 (in Estonian). English text available at https://www.riigiteataja.ee/en/eli/529012015010/consolide (most recently accessed on 20.2.2015).

26 Article 5 (2) of the CRM Directive.

27 Consolidated version of the Treaty on the Functioning of the European Union (OJ C 115/47). Available at http://eur-lex. europa.eu/legal-content/EN/TXT/?uri=CELEX:12012E/TXT (most recently accessed on 9.4.2015).

28 Recital 19 of the CRM Directive.

29 See Proposal for a directive of the European Parliament and of the Council on collective management of copyright and related rights and multi-territorial licensing of rights in musical works for online uses in the internal market. Available at http:// ec.europa.eu/internal_market/copyright/docs/management/com-2012-3722_en.pdf(most recently accessed on 5.3.2015).

30 Recital 3 of the proposal for a CRM directive. 
in Estonia shall also be deemed to be a collective management organisation that is entitled to manage the rights of holders of rights collectively also in cases of compulsory and extended collective management. ${ }^{*}{ }^{31}$ This working definition could form a basis for a draft law.

\section{Competition policy and cultural diversity}

The applicability of competition law to the activities of collective management organisations is a complex legal issue. According to some legal experts, the conventional wisdom is that competitive markets serve the interests of customers and consumers better than monopolies do. Whether, however, this also holds true for collective management organisations is highly disputable. ${ }^{*} 32$

The CRM Directive makes it clear that CMOs are not exempt from the competition rules provided by the TFEU. ${ }^{*} 33$ This means that CMOs' activities should comply with the antitrust rules stipulated in Article 101 of the TFEU and collective management organisations should not abuse their dominant position (TFEU, Article 102) ${ }^{*} 34$. This has also been consistently held in the European case law. ${ }^{*} 35$

Since there are numerous collective rights management organisations in the EU, the European Commission has scrutinised the activities of CMOs in consequence of complaints pertaining to their transparency, governance, and the distribution of royalties collected on behalf of rights-holders. ${ }^{*}{ }^{3}$

This approach is reaffirmed by Commission Recommendation 2005/737/EC, on collective rights management for music services on the Internet. ${ }^{*} 37$ The European Commission confirmed the basic principles of this Recommendation document in the 2008 CISAC $^{*} 38$ decision. ${ }^{*} 39$ On 16 July 2008, the European Commission adopted a decision prohibiting 24 European collective management organisations from restricting competition with respect to the conditions for the management and licensing of authors' public performance rights in musical works. The collective management organisations were found to have restricted the services they offer for authors and commercial users outside their domestic territory. The European Commission took the view that a series of measures taken, including membership and territorial restrictions incorporated into the reciprocal representation agreements concluded between the collective management organisations, constituted infringements of Article $81^{*}{ }^{\circ 0}$ of the EC Treaty and Article 53 of the EEA Agreement. ${ }^{* 1}$ The International Confederation of Societies of Authors and Composers (CISAC) and the European societies launched an appeal against the Commission's decision on the alleged co-ordination of territorial restrictions. To show its support to the appealing European societies, CISAC also intervened on behalf of the societies in their own proceedings. ${ }^{*} 42$ In a series of judgements dated 12 April 2013, the Court partly

31 E. Vasamäe (see Note 12), p. 254.

32 J. Drexl. Collecting Societies and Competition Law. 2007, p. 1. Available at http://www.ip.mpg.de/shared/data/pdf/ drexl___crmos_and_competition.pdf (most recently accessed on 18.3.2015). See also L. Guibault, S. van Gompel. Collective management in the European Union (Amsterdam Law School Legal Studies Research Paper No. 2012-o8, Institute for Information Law Research Paper No. 2012-08), p. 1. Available at http://ssrn.com/abstract=1984015 (most recently accessed on 22.3.2015).

33 Recital 11 of the CRM Directive emphasises the need for compliance with the competition rules.

34 See also L. Gibault, S. van Gompel (see Note 33), pp. 4-5.

35 See, for instance, Case C-351/12, Case C-7/82, and Case C-127/73.

36 C.B. Craber. Collective rights management, competition policy and cultural diversity: EU lawmaking at a crossroads (i-call Working Paper No. 2014/o4, October 2012). Available at http://papers.ssrn.com/sol3/papers.cfm?abstract_id=2161763 (most recently accessed on $18.3 \cdot 2015$ ).

37 Commission Recommendation 2005/737/EC of 18 May 2005 on the collective cross-border management of copyright and related rights for legitimate online music services (OJ L, 21.10.2005, 276).

38 Further information on CISAC, the International Confederation of Societies of Authors and Composers, is available at http:// www.cisac.org/ (most recently accessed on 22.3.2015).

39 Commission Decision COMP/C2/38.698 - CISAC, of 16 July 2008, 'relating to a proceeding under Article 81 of the EC Treaty and Article 53 of the EEA Agreement', C(2008) 3435 final. See also C.B. Craber (see Note 37), pp. 8-9; L. Gibault, S. van Gompel (see Note 33), pp. 2-3.

40 Now Article 101 of the TFEU.

41 A. Andries, B. Julien-Malvy. The CISAC decision - creating competition between collecting societies for music rights. Competition Policy Newsletter 2008/3, p. 53. Available at http://ec.europa.eu/competition/publications/cpn/2008_3_53.pdf (most recently accessed on $18.3 \cdot 2015$ ).

42 Case T-442/o8, CISAC $v$. European Commission. These judgements were given in parallel cases brought by most of the collection societies in the EU, and by the International Confederation of Societies of Authors and Composers. See, for instance, the judgement in case T-416/o8, Eesti Autorite Ühing v. European Commission. 
annulled the referred European Commission decision. However, the majority of the Commission's arguments in favour of establishing a new cross-border licensing system were not actually rejected by the Court.

The central issue here has to do with the potential impact of this decision in the context of transposition of the CRM Directive. It was definitely relevant in the formulation of the basic principles underlying the CRM Directive and for collective management organisations' activities before the adoption of the directive. Since the key findings stated in the decision have been incorporated into the text of the CRM Directive, the implementation of the CRM Directive directly addresses the competition-policy issues surrounding CMOs' activities.

The most relevant norms for licensing rights in the digital arena and competition policy are found in the CRM Directive's Title III, 'Multi-territorial licensing of online rights in musical works by collective management organisations'. According to the explanatory memorandum on the proposal of the CRM Directive, one of the aims of the new regulation is to change copyright licensing schemes on account of the development of a single market for cultural content online, 'notably in the licensing of the rights of authors in musical works as online music service providers face difficulties in acquiring licences with an aggregated repertoire for the territory of more than one Member State'."43 In the CRM Directive, the contradiction between the principle of territoriality of intellectual property rights (IPRs) and the principle of an efficient internal market ${ }^{*} 44$ is overcome by means of the concept of multi-territorial licensing, and it follows the licensing policy proposed by the 2005 Commission Recommendation. ${ }^{*} 5$ Diverging from the contested CISAC model, this new approach does not allow Member States to restrict the allocation of multi-territory licences for musical works, referring to the territoriality principle. On the one hand, Title III of the CRM Directive is aimed at enhancing conditions to make them conducive to the most effective licensing practices of CMOs in an increasingly cross-border context. On the other hand, the cultural diversity factor and repertoires of smaller countries such as Estonia are also kept in mind.

Pursuant to the CRM Directive ${ }^{*} 46$, Member States shall ensure that any representation agreement between collective management organisations whereby a collective management organisation mandates another collective management organisation to grant multi-territorial licences for the online rights in musical works in its own music repertoire is of a non-exclusive nature. It specifies further that the collective management organisation so mandated shall manage those online rights on a non-discriminatory basis. Recital 44 of the directive further explains that exclusivity in agreements on multi-territorial licences would restrict the choices available to users seeking multi-territorial licences and also restrict the choices available to collective management organisations seeking administration services for their repertoire on a multiterritorial basis. Currently, the Estonian Copyright Act does not restrict the freedom of contract such that reciprocal agreements among collective rights management organisations should be only of a non-exclusive nature. In consequence, the Estonian Copyright law has to be amended accordingly. As a result, all representation agreements between collective management organisations providing for multi-territorial licensing should be concluded on a non-exclusive basis.

In this context, it is also appropriate to make reference to the Estonian Competition Act ${ }^{*} 47$, which contains specific regulation on refusal to grant access to an essential facility. ${ }^{*} 48$ The essential-facilities doctrine

43 See the proposal for a directive of the European Parliament and of the Council on collective management of copyright and related rights and multi-territorial licensing of rights in musical works for online uses in the internal market, p. 3 .

44 See, for instance, the Communication from the Commission to the European Parliament, the Council, the European Economic and Social Committee and the Committee of the Regions: A single market for 21st century Europe (COM(2007) 724 final), pp. 3-4. Available at http://aei.pitt.edu/45895/ (most recently accessed on 21.4.2015). The importance of an effective internal market has been pointed out in most documents issued by the European Union dealing with single-market issues. This is a starting point also for planned initiatives in the EU to have a functioning digital single market. Internal market issues have been listed as a priority field on the current European Commission Web site. Available at http://ec.europa. eu/index_en.htm\#priorities (most recently accessed on 21.4.2015). See also, for instance, the background information for the Digital Single Market Strategy for publication in May 2015. Available at http://europa.eu/rapid/press-release_IP-154653_en.htm (most recently accessed on 21.4.2015).

45 Recital 39 of the directive. See also E. Vasamäe (see Note 12), p. 70.

46 Article 29 of the CRM Directive.

47 Konkurentsiseadus. - RT I 2001, 56, 332; RT I, 30.12.2014, 2 (in Estonian). English text available at https://www.riigiteataja. ee/en/eli/519012015013/consolide (most recently accessed on 22.3.2015).

48 According to the Competition Act, "[a]n undertaking in control of an essential facility is required to permit other undertakings to gain access to the network, infrastructure or other essential facility under reasonable and non-discriminatory conditions for the purposes of the supply or sale of goods' (§18 (1)). 
is one framework for conceptualising a refusal to deal, including a refusal to license, as an abuse of market dominance. ${ }^{*} 49$ The authors maintain that the provisions of the Estonian Competition Act can be considered broad enough to cover refusal to license an essential IPR also, as this refers to networks, infrastructure, and 'other essential facilities'. Since Recital 11 of the CRM Directive leaves the competition law intact, this regulation represents an additional possibility for weighing the appropriateness of the activities of a CMO. ${ }^{*}{ }^{5}$

In addition to competition-policy issues, we have cultural diversity considerations. The TFEU*51 requires the European Union to 'contribute to the flowering of the cultures of the Member States, while respecting their national and regional diversity and at the same time bringing the common cultural heritage to the fore'. Recital 3 of the CRM Directive emphasises the function of CMOs in supporting cultural diversity: 'Collective management organisations play, and should continue to play, an important role as promoters of the diversity of cultural expression, both by enabling the smallest and less popular repertoires to access the market and by providing social, cultural and educational services for the benefit of their rightholders and the public.' The CRM Directive articulates a framework to assure the dissemination of small repertoires and thereby enhance cultural diversity. ${ }^{*}{ }^{2}$ Collective management organisations have a right to require another $\mathrm{CMO}$ to represent them in multi-territorial licensing, which facilitates the licensing process and makes all repertoires accessible to the market for multi-territorial licensing. The framework described reduces the number of transactions that online service providers otherwise need perform to offer services. This should facilitate the development of new online services and lower the price that consumers have to pay.

Collective management organisations that are not willing or not able to grant multi-territorial licences directly in their own music repertoire should be encouraged on this basis to mandate other collective management organisations to manage their repertoire in a non-discriminatory manner. ${ }^{*} 53$

The CRM Directive has additional safeguard clauses for small CMOs and small repertoires. According to the directive, the CMO subject to the request should manage the 'new' repertoire on conditions identical to those it applies to the management of its own repertoire and the requested CMO should include the represented repertoire in all offers it addresses to online service providers. ${ }^{*} 54$

Despite some criticism in legal literature ${ }^{*} 55$, the authors of this article rather support those arguments that conceptualise the directive as a positive development. ${ }^{*}{ }^{66}$ It is justified for activities of organisations constituting de facto monopolies such as collective rights management organisations to be subject to some restrictions. The authors are of the opinion that the CRM Directive has struck a fair balance in the context of cross-border licensing of musical works.

\section{Supervision of CMOs}

The issue of supervision of collective management organisations is one of the most challenging topics in the context of the transposition of the CRM Directive into Estonian legislation. According to articles 36-38 of the CRM Directive, a Member State should guarantee that the compliance of CMOs established in their

49 For further discussion, see M. Hagström, R Rüütel. Konkurentsiõigus ja praktika (Competition Law and Practices). - Äripäev 2010, pp. 88-102; J. Drexl et al. Copyright, competition and development: Report by the Max Planck Institute for Intellectual Property and Competition Law, Munich. 2013, pp. 69, 92, 260. Available at http://www.wipo.int/export/sites/www/ ip-competition/en/studies/copyright_competition_development.pdf (most recently accessed on 17.3.2015).

50 In Estonia, one case came before the Competition Board in 2009. After receiving a complaint from local users of works on the licence-fee structure, the Estonian competition agency tested the appropriateness of royalty rates of CMOs. Finally it was decided that the differentiated fees did not violate competition law. Decision available at http://www.konkurentsiamet.ee/public/MT_Eesti_klubide_Liit_Eesti_Fonogrammitootjate_hing_Eesti_Autorite_hing_Eesti_Esitajate_Liit_ otsus_28_10_2009.pdf (most recently accessed on 15.3.2015).

$51 \quad$ TFEU, Article 167 (1).

52 Article 30 of the CRM Directive.

53 Recital 44 of the CRM Directive.

54 The CRM Directive's Article 30 (3) and (4).

55 According to some critics, the implementation of the CRM Directive might lead to a lack of cultural diversity, since managing the main (popular) repertoire benefits a CMO more and thereby the niche repertoire could be left aside. It has also been pointed out that CMOs fulfil important non-economic functions and that leaving smaller CMOs facing the competition might lead to disappearance of such CMOs as manage mainly small (niche) repertoires. See. J. Drexl. Competition in the field of collective management: Preferring 'creative competition' to allocative efficiency in European copyright law. - P. Torremans (ed.). A Handbook of Contemporary Research. Edward Elgar Publishing 2007, p. 272. See also C.B. Craber (see Note 37), p. 11.

56 E. Vasamäe (see Note 12), p. 45. 
territory with the provisions of the CRM Directive is monitored by competent authorities designated as having that responsibility. There has been no state supervision system established so far in Estonia. ${ }^{*} 57$ Therefore, the implementation of the CRM Directive requires radical changes of the Estonian copyright law in this respect. A strategic decision should be made with regard to which authority in Estonia is the one to be notified of activities or circumstances that allegedly violate the provisions of the CRM Directive transposed into Estonian law. ${ }^{*} 58$

In general terms, Estonia has three main options with respect to the supervising institution. Firstly, Estonia could rely on the existing copyright committee, which, inter alia, resolves disputes related to copyright and neighbouring rights by way of conciliation of the parties. ${ }^{*} 59$ The committee does not have any power to impose sanctions, and it consists of representatives of CMOs and of institutions that would initiate the supervision procedure. On account of these conditions, the committee is not suitable for the implementation of Article 36 of the CRM Directive.

With the second option, the supervisory tasks could be shifted to the Patent Board of Estonia, which is a government agency under the Ministry of Justice. This, however, requires structural changes to the Patent Board and considerable investments in capacity-building of its personnel with respect to copyright, related rights, and collective management thereof. The Ministry of Justice as a government entity responsible for intellectual property issues, including copyright and related rights ${ }^{*} 60$, could be considered as a third option. Although no official decisions have been made yet, the authors of the article consider the Ministry of Justice to be the appropriate institution for fulfilling the tasks of the competent authority since it already possesses the required competence.

In addition to designation of an institution supervising CMOs, it is necessary to choose a suitable form of control. The CRM Directive provides that competent authorities should have the power to impose appropriate sanctions or take appropriate measures where the provisions of national law adopted in implementation of the CRM Directive have not been complied with. ${ }^{*}{ }^{1}$ The CRM Directive does not restrict the choice of Member States as to competent authorities, nor with regard to the nature of the control over collective management organisations. ${ }^{* 62}$ The CRM Directive does, however, require sanctions and other measures to be 'effective, proportionate and dissuasive'. ${ }^{6} 63$

These limitations notwithstanding, Estonia still has some room for manoeuvring. One way forward could be to supervise CMOs' activities within the legal framework established by the General Part of the Economic Activities Code. ${ }^{*} 4$ The General Part of the Economic Activities Code enumerates two kinds of control measures: 1) ex ante (the entity should have an activity licence prior to commencement of its activities) ${ }^{*} 65$ and 2) ex post (the entity is required to submit a notice to the registrar upon commencement of its activities). ${ }^{* 66} \mathrm{~A}$ third option is not to apply any kind of ex-ante or ex-post supervision measures to

57 Estonia is one of the very few countries where such a supervisory system has not been introduced yet. Many countries already have such measures in force. Examples are Latvia (the Latvian Copyright Law's Section 67 stipulates that collective management organisations should have a permit and that the permits for the administration of economic rights on a collective basis shall be issued and cancelled by the Ministry of Culture), Hungary (where the activities of collective management organisations are linked to prior registration of the organisations and their activities are monitored and supervised by the Hungarian Intellectual Property Office, pursuant to Sections 91-92P of the Hungarian Copyright Act), and the Czech Republic (pursuant to the relevant copyright law's Sections 98-99, there should be authorisation obtained from the Ministry of Culture to execute activities of collective management, and the Ministry of Culture also supervises the activities after giving authorisation).

59 The Copyright Act's $\$ 87$ (1) 4).

60 Vabariigi Valitsuse seadus (Government of the Republic Act). - RT I 1995, 94, 1628; RT I, 5.11.2014, 2. Unofficial translation available at https://www.riigiteataja.ee/en/eli/517112014001/consolide (most recently accessed on 22.3.2015). Section 59 (1) of the Government of the Republic Act stipulates that the sphere of governance of the Ministry of Justice encompasses also co-ordination of the field of intellectual property.

63 Article 36 of the CRM Directive.

64 Majandustegevuse seadustiku üldosa seadus. - RT I, 25.3.2011, 1; RT I, 29.6.2014, 1 (in Estonian). English text available at https://www.riigiteataja.ee/en/eli/522082014004/consolide (most recently accessed on 22.3.2015). For the purpose of clarification, it should be mentioned that this code transposes the Services Directive into Estonian legislation. See also Directive 2006/123/EC of the European Parliament and of the Council of 12 December 2006 on Services in the Internal Market. - ELT L 376, 27.12.2006, pp. 36-68.

65 Sections 16-28 of the General Part of the Economic Activities Code Act.

66 Sections 14-15 of the General Part of the Economic Activities Code Act. 
CMOs. Instead, it could be stipulated that the competent authority (most likely the Ministry of Justice) is obliged to act when a CMO violates requirements transposed from the CRM Directive into the Copyright Act (general supervision).

Under this approach, CMOs should follow the requirements set forth in the Copyright Act. However, they are not required to submit a notice of their activities and do not need to obtain an activity licence. In the event that an interested party (e.g., a CMO member or a user) considers a CMO's activities to violate the Copyright Act, said interested party can notify a local competent authority and relevant proceedings based mainly on the Copyright Act shall follow.

The authors prefer a differentiated approach that considers the nature of a CMO. Ex-ante measures of any sort requiring prior authorisation should be deemed non-proportional and be excluded in all cases

Collective management organisations granting multi-territorial licences to online rights in musical works ${ }^{*} 67$ should be subject to ex-post supervision measures and submit the relevant data to the register of economic activities. ${ }^{* 68} \mathrm{~A}$ higher supervision standard is justified by the fact that CMOs issuing multiterritorial licences have considerable market power. In addition, if the competent authority has prior information on the scale of CMOs' activities, the supervision task of the state can be fulfilled more efficiently. All other CMOs should be subject to general supervision. This means that they do not have to submit any data similarly to CMOs granting multi-territorial licences (an ex-post measure). The supervising institution shall investigate and impose sanctions if necessary only after receiving relevant notification from an interested party.

When one is establishing a regulatory framework to supervise CMOs' activities, it is necessary to consider the General Part of the Economic Activities Code, the Law Enforcement Act ${ }^{*} 69$, and the Substitutive Enforcement and Penalty Payment Act ${ }^{*} 70$. A conceptual issue to be decided upon is whether the provisions regulating supervision are to be in the Copyright Act or distributed among several acts. It is necessary to bear in mind that the General Part of the Economic Activities Code, the Law Enforcement Act, and the Substitutive Enforcement and Penalty Payment Act stipulate the general framework for supervisory activities in Estonia and that the specific provisions should be stated in a law regulating the particular field of law of relevance. This approach is supported by the wording and logic of the General Part of the Economic Activities Code, which stipulates that 'in the cases provided by law an undertaking is required to submit a notice to the registrar on commencement of economic activities in a relevant area of activity prior to commencement of economic activities' (emphasis mine) ${ }^{*} 71$. The collective management of copyright and related rights is regulated in the Copyright Act. Therefore, all specific norms regarding supervisory issues should be included in that act as well. The inclusion of the relevant provisions in the Copyright Act could facilitate legal clarity and awareness among the stakeholders.

\section{Conclusions}

The adoption of the CRM Directive and its transposition create several challenges. Estonia has to identify the most appropriate way of transposing the directive. The problems can be divided into the following categories: 1) the legal form of collective management organisations, 2) compatibility of CMOs' activities with competition regulations (with respect to abuse of dominant position), 3) cultural diversity, and 4) supervision of collective management organisations.

The Estonian Copyright Act requires a certain legal form (that of a not-for-profit association) for establishment of a CMO. After analysis of the final text of the CRM Directive in light of the European Court of Justice case law, it can be argued that Estonia could actually retain its definition of collective management organisations in its copyright law. Nevertheless, it might be reasonable to broaden the definition in

67 Title III of the CRM Directive.

68 For additional information on the register of economic activities, see https://mtr.mkm.ee/ (most recently accessed on 22.3.2015).

69 Korrakaitseseadus. - RT I, 31.12.2014, 28 (in Estonian). English text available at https://www.riigiteataja.ee/en/ eli/528012015003/consolide (most recently accessed on 23.3.2015).

70 Asendustäitmise ja sunniraha seadus. - RT I 2001, 50, 283; RT I, 12.7.2014, 1 (in Estonian). English text available at https:// www.riigiteataja.ee/en/eli/522012015001/consolide (most recently accessed on 22.3.2015).

71 Section 14 (1) of the General Part of the Economic Activities Code. 
Estonian legislation, following the wording of the directive and guaranteeing the most effective implementation of relevant EU norms.

A collective management organisation's activities should not constitute abuse of dominant position. Since Estonia has a sufficient regulatory framework to address this issue, no changes are required at the moment in this quarter.

Although the proposal of the CRM Directive published in 2012 brought some criticism associated with its impact on cultural diversity, the final version has resolved some initially problematic questions. For instance, there can be found balancing norms for small CMOs and small, niche repertoires guaranteeing the equal treatment of such repertoires while represented by other CMOs. The directive also obliges CMOs to include the represented repertoire in all online service offers.

Establishment of supervision of collective management organisations is one of the most complicated issues for Estonia to be addressed during the transposition process. There has been no state supervision system established so far in Estonia. Therefore, the transposition of the CRM Directive requires important changes to the Estonian copyright system. Firstly, there is a need to designate an appropriate institution to supervise CMOs' activities. Secondly, a suitable form of control has to be chosen. The authors are of the opinion that the appropriate supervising institution could be the Ministry of Justice as government body responsible for the field of intellectual property. Considering various forms of control, in turn, the authors of this article prefer ex-post control measures for CMOs granting multi-territorial licences. For all other CMOs, general supervision is sufficient.

The general framework for supervision is provided by the General Part of the Economic Activities Code, the Law Enforcement Act, and the Substitutive Enforcement and Penalty Payment Act. The specific provisions pertaining to supervision of CMOs should be added to the Copyright Act. This is the approach that would enhance the legal clarity the most. 